\title{
Education and Ignorance: Between the Noun of Knowledge and the Verb of Thinking
}

\author{
Tomasz Szkudlarek ${ }^{1} \cdot$ Piotr Zamojski ${ }^{1}$
}

Published online: 29 March 2020

(c) The Author(s) 2020

\begin{abstract}
In this paper we look at the relations between knowledge and thinking through the lens of ignorance. In relation to knowledge, ignorance becomes its "constitutive outside," and as such it may be politically organised in order to delimit the borders of the right to knowledge [the "ignorance economy," see Roberts and Armitage (Prometheus 26 (4): 335-354, 2008)]. In this light, the notion of a knowledge-based society should be understood as a society structured along the lines of knowledge distribution: the rights of possession of and access to knowledge demand that ignorance is planned and executed as the condition of their establishment. In relation to thinking, ignorance appears differently. According to Rancière, the teacher's ignorance conditions the student's appearance as Anthropos, a being who can be asked: what do you think about it? Hence, we are dealing with the ambiguity of ignorance which seems to be both the criterion of social exclusion, and the condition of emancipation. Following this thread with reference to Heidegger's discourse on thinking, we would like to explore the possibility of comprehending knowledge and education beyond the relations of ownership and demands of productivity. Following Rancière, we may say that thinking — as displacing the notion of ignorance-stands in the position of "politics" and questions the ways knowledge societies are structured as "police orders" along the lines of knowledge possession and exclusion.
\end{abstract}

Keywords Ignorance $\cdot$ Knowledge-based society $\cdot$ Thinking $\cdot$ Education

\section{Preliminary Remarks}

The connection between ignorance and education, traditionally construed in the framework of the Enlightenment crusade against ignorance, has been invigorated in recent years by numerous references to Jacques Rancière's provocative book where teacher's ignorance is seen as a condition of emancipatory education, and where inequalities between students' intellectual capacities should be ignored rather than turned into a target of pedagogical

Tomasz Szkudlarek

tomasz.szkudlarek@ug.edu.pl

Piotr Zamojski

piotr.zamojski@ug.edu.pl

1 University of Gdańsk, Gdańsk, Poland 
intervention. According to Rancière (1991), the teacher's ignorance conditions the student's appearance as Anthropos, a being who can be asked: what do you think about it? We will refer to this Rancièrean position later in the paper. However, there is one more context in which ignorance has been discussed and which we want to emphasize. Originally, it appeared in the debates on knowledge economy that highly influenced the tone of educational debates and the blueprints of education policies in recent decades. In that particular iteration, knowledge is seen as capital, and restrictions in the access to knowledge, which one may call the production of ignorance, like patent policies or the enforcement of intellectual property rights, are seen as the condition of securing the (economic) value of knowing.

The shifts and possible collisions between the various modes of ignorance relate to the rearrangement of the dominant understanding of education. The Modern imaginary, where ignorance was supposed to be overcome by the pursuit for knowledge through universal education and lead to social emancipation, has been displaced by the discourse of knowledge economy and its emphasis on skills necessary in the production of knowledge that contributes simultaneously to a distribution of ignorance. These interrelated shifts are in the background of our interest in using the lens of ignorance in the investigation into the relations between knowledge and thinking and how these affect our educational and political imaginaries.

Knowledge and thinking are at the core of what we know as education. As we will speak of them extensively further in the paper, it should suffice now to give a practical example to illustrate their somewhat problematic relations in today's education driven by the market logic, where high-stakes testing has become the ultimate instrument of assessing its validity. In conversation with our students we have heard that some of them were given a peculiar piece of advice concerning their strategy of answering test questions in secondary school finals: if you do not know the answer to a particular question, do not think and proceed to questions you can answer right away; later will you have time to come back to those problematic ones. However anecdotal it is, this piece of advice points to a serious question of the status of thinking in education that seeks accountability and, therefore, must privilege the countable.

Another distinction that we speak about arrived in the process of writing this paper. Very quickly have we encountered a problem with some inconsistencies of language. The first part of our paper addresses the notion of knowledge, and here we speak of structures and borders, of knowledge seen as a product which has a market value, of politics (in the traditional sense of the word) and economy as the powers which define education in terms of investment. We speak of knowing that becomes reified, commodified, that is dreamt of as a "thing" that can be managed and exchanged for other things. In the second part we speak of thinking which, in fact, starts with things. But these things are thought of as interesting as long as they trigger processes: they make us think and such thinking dissolves the solid; it positions us in-between what there is; it reminds us of the very process of being as flowing through beings. Interestingly, the language of these two parts adjusts itself not to where they start, but to that towards which they aim: it "follows" them. In the first part it follows from processes (like learning) to objects, structures, exclusions and borders. In the second part, it departs from objects towards things and thinking, which brings us close to the very flux of being. The language of the first part of the paper is thus organised around nouns, while in the second part it oscillates around verbs.

A difficulty with theorizing education, we think, is that it cannot be narrated in one language. It has to speak both of structures and of processes, it has to shift between the solid and the liquid. In this respect, as we shall conclude, it operates close to what Rancière 
describes as the tension, or oscillation between "police" and "politics," between what Laclau and Mouffe called "politics" and "the political," and between what Heidegger called "the ontic" and "the ontological". Remote as these distinctions originally may be, they all speak to the productive tension between that which "is" (like Heidegger's beings, or the ontic) and the very process of their becoming: the Being of beings, or the ontological in Heidegger's language. What really matters, and what always slips through our articulations and cannot be made clear, is the very relation between the two, "the third" in between. It is tempting to think that this is where education is positioned as the mediating possibility: in this particular case, between the noun of knowledge and the verb of thinking.

\section{Knowledge-Ignorance}

The way we think nowadays of the relations between knowledge, politics and education has been strongly influenced by the work of Michel Foucault. Even though Foucault did not speak of education other than as of one of the many sites and practices (like instruction, examination, etc.) where disciplinary power grows to the status of the defining logic of the modern state, the position of education, broadly understood, in his theoretical constructions is far stronger. As Keith Hoskin (1990) once noted, "the operation of power-knowledge needs a third term: ... can that term be other than an educational term?" (p. 52). ${ }^{1}$

The current variety of the knowledge-politics connection is also strongly mediated by education. It has been informed by the discourse of the knowledge society and its preceding concepts, like the knowledge-based economy or the information society, and these notions refer to education with an unceasing frequency. The vision of the knowledge society is not clear, however. It connects vague concepts and metaphors that form an ideological structure which implies, roughly speaking, that the knowledge economy builds (or needs) a knowledge society composed of life-long learning individuals and organisations, that people's knowledge and skills are valuable assets in such societies, and that the best way of providing for economic growth and social welfare is investing in their learning. In some manifestations of this discourse, human capital investment, as guided by the logic of competition, is balanced by investments in social capital; therefore, it is not only individuals, but also their communities, families and cultures that need investment, that learn, and that therefore "count". In general, the links between knowledge, politics and economy are inevitably mediated by education, usually re-labelled (with important negative consequences, see Biesta 2006) as learning.

This discourse, including its educational component, is clearly dominated by economic rationality to the extent of "genre colonization" (Leitch and Roper 1998). However, it has its socially conscious, more spiritual and utopian dimension. This dimension has been expressed in the discourse of social capital, in future-oriented sociological predictions (for instance in Daniel Bell's forecast that postindustrialism will promote policies oriented towards public good rather than towards cost reductions and economic rationality, Bell 1976, as cited in Jessop 2008) and in such globally circulated documents as the famous UNESCO report written under the guidance of Jacques Delors (1996). The authors of this report speak about education as "the necessary utopia" believed capable of resolving

\footnotetext{
1 In this section we are using excerpts from a previously published chapter (Szkudlarek 2016), where the relation between knowledge society and ignorance is discussed more extensively and systematically.
} 
tensions between the global and the local, the universal and the individual, between tradition and modernity, long-term and short-term considerations, competition and equality of opportunities, between the expansion of knowledge and the limited capacities of its being absorbed by individuals, and-last but not least-between the material and the spiritual (Delors et al. 1996). Fully aware of the pressure of economy and of the practical expectations educational audiences have of schools, the authors stress the social, the existential and the ethical as the remedies for the risks and damages brought by the rapid increase in knowledge production, globalization and economic uncertainty. And yet, in spite of its holistic and humanistic attitude, their report — on the rhetorical level, transmitted already by the reference to "treasure" in title of the book-subscribes to the economic rationality which it claims to transcend. This connection is made explicit in a parable the authors use to explicate the nature of "treasure" in learning. Using La Fontaine's fable on a ploughman who buried treasure in his field to prevent his children from selling the land, they conclude that nowadays it is learning rather than laborious cultivation of land that counts. This transformation of treasure strictly reflects the transformations of capital in modern societies. Investment in land and labour were the factors of production in the classic economy. Delors's economy is a knowledge economy that depends on the "collective ability to leverage what .... citizens know" (Neef 2009, p. 5). Delors and his colleagues hope that learning/knowledge will lead from focusing on economic growth to human development (title of Chapter 3 of the report), as well as to a world society and democratic participation. However, economic rationality has costs.

The policies that are involved in this economically informed ideology include competing ideas of investing in people and their knowledges, on the one hand, and cost reductions on the other. As Western economies compete globally with cheaper states with lower wages and less abundant welfare provisions, in neoliberal policies it was cost efficiency rather than growing investment that in fact became the chief aim of reforms in the public sector, which still-in spite of the long-lasting efforts to "rationalize" it along the lines of "new public management"- caters to a vast segment of educational provisions. The dominant, globally promoted solution to this conflict is private investment to supplement deficiencies in public expenditures. For instance, the rapidly growing demand for higher education qualifications was met in many countries with liberalization of state regulations that facilitated the establishment of private, tuition-based higher education institutions. In Poland, for instance, about 300 such institutions were founded in the 1990s, and their demand for academic faculty was resolved by allowing university teachers in public universities to engage in "double full time" employment. Between 1990 and 2005, the number of tertiary education students increased five times, with a comparatively minimal increase in numbers of academic teachers-a 64\% increase between 1990 and 2010 (Stankiewicz 2018, pp. 180-181).

Apart from inconsistencies in the daily practices of the knowledge economy, like mixing the rhetoric of investment in human learning with permanent cost-reduction policies, there is a fundamental difficulty with how we understand the guiding notions of this ideological position: the concepts of the knowledge society, the knowledge economy, knowledge workers, and even the very concept of knowledge are far from clear, not only in theoretical investigations, but also in policy documents. For example, the call for proposals in the EU's 6th Framework Programme ${ }^{2}$ lists such research areas as "Improving the generation,

\footnotetext{
${ }^{2}$ Framework Programmes have been the main agenda for financing large, collaborative, internationallybased research projects within the EU and associated countries.
} 
distribution and use of knowledge and its impact on economic and social development", "Options and choices for the development of a knowledge-based society" and "The variety of paths towards a knowledge society". Further, in the section on specific objectives, we are encouraged to "examine the public and private good characteristics of knowledge and to better understand its functions in the European economy and society." (FP 6 Specific Programme..., 2004-2006, p. 7). In other words, we need to research and promote the development of a knowledge-based society, but we have no clear idea of what a knowledge society is.

The figure of the knowledge society appears to be, in this account, a rhetorical figure. In terms of Ernesto Laclau's $(2005,2014)$ theory, it is an empty signifier. In Laclau, the role of such signifiers is to provide ground for political identities in conditions of social heterogeneity, or the fundamental lack of defining logics which could guide attempts at the reconciliation of conflicting social demands. Because society cannot be construed by logical means (Laclau is critical of the Hegelian tradition, and of Marx in particular here; there is no historical logic or structural determination that would define the course of social changes), political identities must be construed rhetorically. Such notions as "nation","democracy"'social justice" or "knowledge society" cannot be precisely defined, and it is precisely because of this impossibility that they can operate as integrating factors, uniting scattered and conflictual demands into hegemonic policies.

What this juxtaposition of the promotion of knowledge society with Laclau's theory suggests is that knowledge, learning and education are apparently used as empty and hegemonic signifiers nowadays: they rhetorically create the foundations of one of the nowadays competing political totalities. The discourse of the knowledge society helps to give meaning to such processes as the loss of jobs in industry or the precarization of employment among large cohorts of higher education graduates (Standing 2011). It hides behind its elevated rhetoric the divisions and exclusions which build "really existing" knowledge societies. Every social structure is built of differences, and the construction of the knowledge society depends not only on the lines of knowledge production, innovation and learning, but also on the lines of knowledge exclusions. Knowledge can only be defined in relation to the lack of knowledge, to ignorance as its "constitutive outside" in Laclau's terms, as that which defines its limits, and, thus, marks its territories. Critical theories have long spoken of the destruction, appropriation and exploitation of indigenous knowledges and of the exclusions from knowing, as well as of the narrowing domain of knowledge commons, which nowadays have to be purposefully reconstructed and kept alive as fringe, avant-garde projects of cultural alternatives. The humanistic dimension of this discourse-here represented by Jacques Delors's report—obliterates such exclusions and subsumes the structure of knowledge inequalities, produced as such in the course of turning knowledge into capital, into the all-inclusive utopia of global learning for global citizenship.

To put it succinctly, the construction of knowledge in contemporary knowledge societies implies the operation and the construction of ignorance. It relates to the transformation of knowledge production and distribution from common knowing and curiosity-driven creativity, the results of which are shared in "knowledge commons," to profit-driven and procedurally-controlled industrial knowledge production in enclosed domains, followed by protected ownership rights. If knowledge is to "count", that is, if it should function as an advantage in market competition, it must not be accessible to anyone for free.

The capitalization of academic knowledge affects academic institutions in numerous ways, but its most general impact can be described as undercutting the classic idea of the unity between research and education. In a research project run in four European universities (Dahlgren et al. 2007), several aspects of such separation were identified. 
One illustration is a case reported by one of the students in a university in Poland. A part-time academic teacher, a psychologist also working in a private consultancy company, interrupted her presentation during class to announce that she could not give the students more details because that would constitute selling her knowledge too cheaply. Instead, she invited them to her private company, which provoked indignation on the part of the students. The interview providing this information was conducted in 2002 , when such cases were scarce. In 2015, the same university changed the employment rules for its research staff, and all contracts were supplemented with clauses that prohibit employees from publishing research results and from including them in course content until an internal office decides whether they might be commercially valuable.

One of the hypothetical interpretations of such cases in the aforementioned research is that we are witnessing a shift in what can be called "institutional pacts" linking universities with their social milieus (European Commission 2005). The emerging pact would be split into two different traits, mediated by two separate "products" of academic work. Both relate to the construction of what Etzkovitz and Leydesdorff (1997) called a "triple helix" of relations between the world of academe and its political and business milieus. The first pact would link the university to industry on the corporate side, and it is mediated by knowledge production. The second pact would link the university to industry on the labour side, and this one is mediated by skills production.

This separation seems to be supported by more and more evidence nowadays, and its theoretical conceptualization can be found in Marxist and post-Marxist approaches to the knowledge economy. The classic account on the emergence of capitalist economy assumes that there were two necessary conditions to be met: the production of capital, and the production of the working class (Marx 1999 [1887]). The latter was based on the enclosure of common land and the eviction of "commoners," so that they had no legal means of survival other than wage employment. The worker is, in this perspective, a person who has nothing but his/her hands to sell. It is often claimed that the current transformation of knowledge into capital involves a similar movement (e.g. Phillips 2005; Zeller 2008; Jessop 2007). The massification of higher education is aimed at the production of knowledge workers, and as such they do not have to be equipped with advanced knowledge, nor are they expected to have it by their employers. If today's economy is driven by knowledge production, its possession cannot be expected of its workers. What is needed instead is that they have the skills necessary for such production (Szkudlarek 2010).

In this respect, the knowledge economy and its correlate knowledge society emerge within a logic similar to that which guided the emergence of earlier forms of capital. Jessop (2007) describes the commodification of knowledge, including the resistance to its devastating effects, as following the same stages as those that could be identified in the process of turning land, labour, and money into factors of production and capital in earlier phases of capitalism. The current tendencies to, on the one hand, subordinate knowledge to measurable "impact factors", to integrate it into the flow of monetary capital (knowledge-technology transfer policies), to expand the intellectual property rights regulations, etc., and, on the other hand, the emergence of the "knowledge commons" movement, especially in its more mainstream varieties, like open access publications, present exactly the same logic as that pertaining to the commodification of earlier forms of assets. Both these movements are part of the same political logic of knowledge capitalism and they clearly repeat earlier developments of the system.

In this context, the split between skills education and knowledge education in academic institutions should be read in a radical sense, as a condition of the construction of knowledge capitalism. Its development implies the production, distribution, and management of 
ignorance as the border of knowledge enclosures. As Joanne Roberts and John Armitage write (2008),

the knowledge economy is precisely rooted in the production, distribution, and consumption of ignorance and lack of information. What we are suggesting, then, is that the so-called knowledge economy is one wherein the production and use of knowledge also implies the creation and exploitation of ignorance. For not only knowledge but also ignorance now plays a main role in the formation of advanced global capitalism. (p. 345)

To put it differently, when knowledge, instead of being a common good that overcomes ignorance and enables emancipation and rationalisation of social relations, becomes a commodity that one can produce, sell, or purchase, it cannot be shared freely. It starts to be clear that some people have to stay ignorant about certain matters; that knowledge economy, and with it economically controlled education, is about distribution of who knows and who doesn't know what, rather than about popular enlightenment. Education in Modernist sense, i.e. as acquisition of knowledge and the construction of emancipated peoples is being displaced by the knowledge economy's emphasis on skills and the production of knowledge workers that are ignorant about that knowledge which makes market advantage possible. In other words, the functioning of a knowledge society and a knowledge economy requires making particular persons ignorant about things that concern them, in order to do business or implement a policy (cf. Proctor and Schiebinger 2008).

\section{The Leap into Thinking}

Ignorance, as the constitutive outside of the discourse of the knowledge economy and the knowledge society, is thus incorporated and managed by its very logic. It is included as excluded (cf. Agamben 1998). But does this mean, however, that the discourse of the knowledge economy and the knowledge society does not have an exterior that delimits its presence? On the contrary. What should draw our attention is the absolute absence of thinking within its limits. As not matching the structure of that discourse, thinking is removed from sight. This happens by conceiving knowledge and ignorance in terms of an opposition.

Being opposed, knowledge and ignorance refer to the difference between power to control and being excluded. In this instance, knowledge is an advantage, a desired feature of the subject, being decisive in determining its social, political and economic potency. Hence it is understood as something one possesses and manages: capital. Having knowledge means being aware of things and being able to control them, that is being able to perform the power that knowledge gives (cf. Bacon [1620] 2000). Being related to power, knowledge is an advantage that marks the superiority of its owner, both over the subject of knowledge, and over the ignorant.

However, lack of knowledge, as a state of not being aware of things and of not being able to control them, not only signifies those who are themselves under the control of others. Being ignorant means also being put in the position of being ignored, being not taken into account, being placed out of sight. In this instance, education is conceived in terms of enlightenment, as the move from ignorance towards knowledge, from inferiority towards superiority: the move of emancipation. 
Of course this will never happen: nature itself makes sure of it; there will always be delay, always inequality. But one can thus continually exercise the principle of reducing it... (Rancière 1991, p. 119).

Indeed, as expressed above, according to Jacques Rancière, setting in motion a practice based on the assumption of inequality leads not to the emancipation of anyone, but to the verification of inequality itself. Since having knowledge is an advantage, a property of a person (in both senses) that makes him/her superior to those deprived of it, education, as the move from ignorance towards knowledge, defines the relation between the master and the student in terms of subordination, as the relation between those who have knowledge and those who do not have it (yet). But such a relation, Rancière (1991) argues, is not emancipative, but reproductive: it reproduces the inequality which it assumes, by making education "an indefinite process of coming closer. Never will the student catch up with the master, nor the people with its enlightened elite" (p. 120).

Education can emancipate, but this requires a different assumption shaping the pedagogical relation: that we are all of equal intelligence. Only if we assume equal intelligence a priori, can it become true in educational practice. However, the equality of intelligence is verified through the performance of the equality of ignorance:

...whoever wishes to emancipate someone must interrogate him in the manner of men and not in the manner of scholars, in order to be instructed, not to instruct. And that can only be performed by someone who effectively knows no more than the student, who has never made the voyage before him - the ignorant master. (Rancière 1991, pp. 29-30).

So it is the equality of ignorance that conditions the verification of the equality of intelligence (cf. p. 31), as it is the ignorance of the master that conditions the student's appearance as Anthropos, the being who can be asked: "what do you think about it?" (p. 36). In such a way, the intelligence of the student reveals itself to itself, nurturing the experience of being able to (cf. Masschelein and Simons 2013).

But is this ignorance simply opposed to knowledge as not-knowing? On the contrary, the ignorant student knows her language, her trade, her tool, and their uses (Rancière, 1991, p. 36, cf. p. 28) —what she lacks is the awareness of her intellectual capabilities. The ignorant master knows how to interrogate her students and judge their attention (pp. 29-31), but she does not possess the knowledge about the subject of the lesson. The equality of ignorance does not, therefore, mean an intellectual emptiness of not knowing anything, but it concerns something from the world that is to be examined; it concerns the subject of thought.

\section{Ignorance-Thinking}

Hence, Rancière not only indicates the link between intelligence, ignorance, and thinking, but he also points to thinking (using intelligence) as the realm in which the opposition between knowledge and ignorance falls apart, the realm in which what is understood as knowledge and ignorance is being displaced.

We believe that this displacement can be grasped with reference to the notion of interesse, and that it eventually points beyond the issue of emancipation toward the matters of concern or attention to the world. In order to make that clear, we will now turn to Martin 
Heidegger's lectures on thinking (1968). According to him we think because "some things make an appeal to us to give them thought, to turn to them in thought: to think them" (p. 6).

So it starts with a thing. Naturally a thing is not an object. It is not made for use in our everyday trade and traffic (cf. Heidegger 1962, p. 439), it is not functionally involved in [Bewandtnis] other objects (p.115), is not ready-to-hand [Zuhandenheit] (p. 98). An object [der Gegenstand] — something which stands over against (Heidegger 1977b, p. 162) —is an effect of re-presentation [Vor-stellen], which is being set upon [stellen] for ordering [bestellen] as standing-reserve [Bestand] (Heidegger 1973, p. 87, 97; 2000, p. 72, 83; 1977a, p. 17). An object is a resource not to think about, but to be calculated in our enterprises (cf. 1977b).

By contrast, the thing refers to "anything that in any way bears upon men, concerns them, and that accordingly is a matter for discourse" (Heidegger 1971, p. 174). So if objects are managed, things are posing questions. The thing gathers meanings of human concern; it focuses people's attention not as a resource (standing-reserve), but as a selfstanding and intrinsic part of their world.

Therefore the thing is thought-provoking; it gives us to think (Heidegger 1968, p. 4, 6); it is the beginning of thinking. In order to think one has to move from surrounding objects of daily disposal towards a thing calling on us to think (p. 115).

Heidegger writes:

"Thinking is thinking when it answers to what is most thought-provoking" (p. 28).

Originally this sentence says:

“Das Denken denkt, wenn es dem Bedenklichsten entspricht” (Heidegger 1952/2002, p. 30). ${ }^{3}$

This could be rendered literally as:

"Thinking thinks when it responds and corresponds to what is the most important to think about."

First of all, we must acknowledge Heidegger's leitmotif, ontological difference, turning us from being [das Seiende] towards Being [sein]. Thinking, in his argument, is not conceived of as a noun [das Denken], but as a verb [denken]. It is something that happens, proceeds, moves, and so it cannot be grasped with the help of intellectual tools delivered by a Western metaphysics that perceives what stands-still and is a result of something else, what is stable, closed, and can be calculated, ordered and managed - an object (cf. Heidegger 1973, 2000). Thinking is not an object to possess. It is not an outcome that could be owned. It is not someone's desired feature, a piece of capital increasing one's possibilities in life. Thinking is a path, a way of being, one of which one can be deprived.

Let us repeat:

"Thinking thinks when it responds and corresponds to what is the most important to think about."

\footnotetext{
${ }^{3}$ Fully acknowledging the skills of F. D. Wieck and J. Glenn Grey, who translated Heidegger's Was heißt denken?, we have decided, nonetheless, to recall the original of this phrase because we wish to refer to those meanings that, in the case of this particular sentence, require a literal rendering.
} 
Thinking, therefore, is a response to a call of the thing to turn towards it in thought. Thinking is a response to something in the world that is thought-provoking, that gives us to think (Heidegger 1968, p. 4). It is a relation to a thing that inclines us towards itself, touches and concerns us, as that which is the most serious [das Bedenklichste], what is most to be thought about. Therefore, thinking is a gift from the world that requires a kind of attention that is sensitive not to the attractiveness and functionality of objects, but to the seriousness and importance of the thing. Thinking requires being interested in the world; that is, it requires to be inter-esse: "to be among and in the midst of things, or to be at the center of a thing and to stay with it" (Heidegger 1968, p. 5).

To be interested does not mean to control, to manage objects (revealed in the ordering mode as standing-reserve), but to listen, to be attentive, to be near, to be in the neighbourhood (Heidegger 1968, p. 12, 17; 1971, p. 166, 177). Heidegger calls this attention as being drawn.

At first sight, such a way of being could be opposed to ignorance. Inter-esse signifies letting appear, being turned to, paying attention to, and not ignoring (the world or a thing). However, in such a case ignorance does not simply mean being unaware of things (as it was when ignorance was opposed to knowledge), but it also means not paying attention-which seems to be also the case of knowledge concerning objects in the realm of Enframing [Gestell].A technological mode of revealing the concealed, in which all that presents itself appears as an object ("objectness," as Heidegger calls it; Heidegger 1977b, p. 163) is not inter-esse. It orders the re-presentations of things as a standing-reserve of Ge-stell. Therefore, such knowledge is not interested in things, is not paying attention, that is, it ignores everything that does not fit its frame. Paradoxically, it could thus be called ignorant.

Does this mean that thinking is opposed to ignorance? On the contrary: ignorance makes the movement of thought ongoing. However, this movement requires ignorance to stem from inter-esse, that is, it requires ignorance to provoke the knowing being into being drawn by the thing of its interest.

In other words: thinking requires a play between knowledge and ignorance, which makes us both aware and attentive, but simultaneously not sure and without power to control. In Heidegger's (1968) terms, it is about the withdrawal of the thought-provoking thing:

What withdraws from us, draws us along by its very withdrawal, whether or not we become aware of it immediately, or at all. Once we are drawn into the withdrawal, we are drawing toward. What draws, attracts us by its withdrawal. (p. 9)

We are attracted to a thing because of the play between what we know and what we do not know. We are paying attention to a thing because of what we do not know, and because of what we are aware of. Both, knowledge and ignorance, drive the movement of thought. However, we are talking here about knowledge that is aware of its limits (of its own ignorance), and about ignorance that is interested, is paying attention, is being drawn. Ignorance that does not ignore.

The withdrawal of what is thought-provoking means that being drawn never reaches its fulfilment. Therefore, thinking is infinite, radically open and, in a way, unproductive (cf. Masschelein 1996). So it does not end with a result that embodies its nature, purpose, or sense. Thinking is not encompassed by its product - in fact, it has not got any product at all. Being drawn into what withdraws as thought-provoking, that is as the most serious thing to think about, does not have its "natural" end. Naturally, one who thinks can stop the movement of his/her thoughts and turn away from the thing of his/her interest. However, stopping does not mean resulting in or producing. Therefore Heidegger (1968) notes: 
(1) Thinking does not bring knowledge as do the sciences.

(2) Thinking does not produce usable practical wisdom.

(3) Thinking solves no cosmic riddles.

(4) Thinking does not endow us directly with the power to act. (p. 159)

But does not thinking bring something to our world? Is being unproductive something more than just being empty, being meaningless? What is the sense of thinking?

Let us turn to Hannah Arendt (2003) here, who reminds us of one of the similes Socrates applied to himself: a gadfly (p. 173). Thinking is a wind, she repeats, following him (and Heidegger), that unfreezes solidified convictions. "Thinking is equally dangerous to all creeds and, by itself, does not bring forth any new creed" (p. 178).

It is therefore destructive in nature; it dismantles the prescribed order of things, disintegrates our knowing; and so it is a painful experience, like a bite of a gadfly to those rooted in, or attached to the current form of status quo. Thinking is dangerous, disruptive; it is an excess that exceeds what is expected, acknowledged, acquired. And although it does not bring forth any new creed, it opens up a space for the new to appear. Hence, apart from its disruptive side thinking is an affirmation of potentiality and refers to an educational imaginary of study practices (Lewis 2015; Vlieghe 2013). ${ }^{4}$

Following Rancière, we may say that thinking, as displacing the notion of ignorance, stands in the position of "politics" not only by questioning the ways knowledge societies are structured along knowledge possession and exclusion, but also by making room in the "police order" for the new to come.

\section{Conclusion}

In Jacques Rancière's political theory, the social world is constituted by two aesthetics. The first one is a categorising, or mapping structure, which distributes social beings along the lines of visibility, audibility, or, in a general sense, availability to the senses. Some things are visible, some other are not. Some humans are visible and audible, some other ones are not. Their visibility is possible in certain places and certain times and impossible in other ones. Subjects can be seen and heard when they appear in the right time and the right place, and it is just some subjects who can be seen/heard in particular places. Such an aesthetic, such rules of the division of the sensible (in Rancière's language), Rancière calls "police" (1999,2010).

The second aesthetic is that of disruption of the first one. It resorts to demonstration, to the appearance of the "wrong" people in the "wrong" places, to claiming space and time for the presence of those who were not expected to be there or to speak. It disrupts the police order and creates conditions for its reconfiguration. This aesthetic is called "politics" by Rancière.

The two modes of ignorance we have referred to in this paper are rooted in these two aesthetics. Ignorance, thus, appears "in the mode of exclusion," as the constitutive outside to the knowledge economy, and, as such, it is absorbed to that economic realm as an

\footnotetext{
${ }^{4}$ Following Giorgio Agamben's philosophy, Tyson Lewis (2015) gives an account of studying in terms of an interminable exploration of some-thing, that preserves a particular ignorance (stupidity), and doesn't lead to any fulfilment (is not productive), but enables pure potentiality, i.e. (im)potentiality. For more elaborated theorisation of the connection between Heidegger's concept of a thing and Agamben/Lewis's concept of study see: Vlieghe and Zamojski (2019).
} 
object to be managed in a way which secures the commodification of knowledge. Ignorance also appears "in the mode of emancipation" in a Rancièrean sense, as linked with thinking and, therefore, involved in an interplay with knowledge that moves the Anthropos towards the thing and its call to give it a thought. As we have suggested in the introduction to this paper, the first of these modes finds its expression in the aesthetic dominated by nouns: it speaks of ignorance as opposed to knowledge, which itself is seen as plural and property - bound objects to be managed. In this aesthetic - the "police" aesthetic of a knowledge society - the reification and commodification of knowledge and the rearticulation of knowledge as capital find a "natural" setting. By the same token, the production and distribution of ignorance become a means of social exclusion, as the ignorant is placed in the position of being ignored. The same mode is one of the key aesthetics of contemporary educational practice, where knowledge is also parcelled into separate chunks, which can be represented, listed, classified, transmitted, absorbed, digested, and excreted in the form of ticks on test sheets, and where ignorance can be battled, marginalised, eradicated, and simultaneously produced, distributed, and ranked.

The second mode appears to be more complex in this respect. As we have suggested, its aesthetic oscillates around verbs, and it speaks not about an opposition, but about a play between knowledge and ignorance, therefore displacing their meanings from the "police" aesthetic of properties, placements, positions, and structures, towards movements, events, and ruptures of "politics." Knowledge and ignorance are in play; they are intertwined as someone's being aware and paying attention, as knowing ignorance, not ignoring and being ignored, but staying among the things of interest (inter-esse), being attentive to, concerned for, drawn into what withdraws. Being in someone's turn toward a thing which is calling for attention, ignorance and knowledge drive the movement of thought that disrupts the standstill of the structure of the status quo, and — as such — makes the thing/the world open for renewal. Therefore, in the aesthetics of "politics," the play of the ignorance that does not ignore and the knowledge that is aware of its ignorance, opens up a space for the experience of being able to happen. In this case, education might be understood as time and space for an unproductive being drawn by what withdraws as the most serious and thought-provoking, by the thing of one's interest. It requires being attentive, sensitive to what appears in the neighbourhood of our Being as calling to give it a thought. Such education is driven by the question: what calls us to thinking?

Open Access This article is licensed under a Creative Commons Attribution 4.0 International License, which permits use, sharing, adaptation, distribution and reproduction in any medium or format, as long as you give appropriate credit to the original author(s) and the source, provide a link to the Creative Commons licence, and indicate if changes were made. The images or other third party material in this article are included in the article's Creative Commons licence, unless indicated otherwise in a credit line to the material. If material is not included in the article's Creative Commons licence and your intended use is not permitted by statutory regulation or exceeds the permitted use, you will need to obtain permission directly from the copyright holder. To view a copy of this licence, visit http://creativecommons.org/licenses/by/4.0/.

\section{References}

Agamben, G. 1998. Homo sacer: Sovereign power and bare life. (D. Heller-Roazen, Trans.) Stanford: Stanford University Press.

Arendt, H. 2003. Thinking and moral considerations. In Responsibility and judgment (J. Kohn, Ed.). New York: Schocken. (Original work published 1971)

Bacon, F. 2000. The new organon (L. Jardine \& M. Silverthorne, Trans.) Cambridge: Cambridge University Press. (Original work published 1620) 
Bell, D. 1976. The coming of post-industrial society. New York: Basic Books.

Biesta, G.J.J. 2006. Beyond learning: Democratic education for a human future. Boulder: Paradigm.

Dahlgren, L., G. Handal, T. Szkudlarek, and M. Bayer. 2007. Students as journeymen between cultures of higher education and work: A comparative European project on the transition from higher education to working life. Higher Education in Europe 32 (4): 305-316.

Delors, J. et al. 1996. Learning: The treasure within. Report to UNESCO of the International Commission on Education for the Twenty-first Century. UNESCO Publishing, Retrieved on 5 February 2020, from https://unesdoc.unesco.org/images/0010/001095/109590eo.pdf.

Etzkowitz, H., and L. Leydesdorff. 1997. Universities and the global knowledge economy: A triple helix of university-industry-government relations. London: Pinter.

European Commission 2005. EU research on social sciences and humanities. Students as Journeymen between communities of higher education and work. Journeymen Final report, HPSE-CT-2001-00068. Retrieved from https://cordis.europa.eu/documents/documentlibrary/82608291EN6.pdf.

FP 6 Specific Programme "Integrating and Strengthening the European Research Area" Priority 7: Citizens and Governance in a knowledge based society Work Programme 2004-2006. Retrieved on 24 March 2020, from https://docs.google.com/viewer?url=http\%3A\%2F\%2Fwww.europafacile.net\%2FFormular i\%2F6PQricerca\%2FBandi\%2FIntegrareSpazioEuropeoRicerca\%2FFP6-2004-CITIZENS_4e5e6 $\% 2 F g \_w p \_200202 \_$_en.pdf\&pdf=true.

Heidegger, M. 1962. Being and time. (J. MacQuarrie \& E. Robinson, Trans.). Oxford: Basil Blackwell. (Original work published 1927)

Heidegger, M. 1968. What is called thinking? (F. D. Wieck \& J. Glenn Gray, Trans.). New York: Harper \& Row. (Original work published 1952)

Heidegger, M. 1971. The thing. In Poetry, language, thought (A. Hofstadter, Trans.). New York: Harper \& Row. (Original work published 1950)

Heidegger, M. 1973. Overcoming metaphysics. In The end of philosophy (J. Stambaugh, Trans). New York: Harper \& Row. (Original work published 1954)

Heidegger, M. 1977a. The question concerning technology. In The question concerning technology and other essays (W. Lovitt, Trans.). New York: Garland.

Heidegger, M. 1977b. Science and reflection. In M. Heidegger, The question concerning technology and other essays (W. Lovitt, Trans.). New York: Garland.

Heidegger, M. 2000. Überwindung der Metaphysik. In M. Heidegger, Gesamtausgabe. Band 7: Vorträge und Aufsätze. Frankfurt am Main, Germany: Vittorio Klostermann. (Original work published 1951)

Heidegger, M. 2002. Was heißt denken? In M. Heidegger, Gesamtausgabe. Band 8: Was Heißt Denken? Frankfurt am Main, Germany: Vittorio Klostermann. (Original work published 1952)

Hoskin, K. 1990. The crypto-educationalist unmasked. In Foucault and education: Disciplines and knowledge, ed. S. Ball, 29-53. London: Routledge.

Jessop, B. 2007. Knowledge as a fictitious commodity: Insights and limits of a Polanyian analysis. In Reading Karl Polanyi for the 21st century: Market economy as a political project, ed. A. Buğra and K. A ğartan, 115-134. Basingstoke: Palgrave.

Jessop, B. 2008. A cultural political economy of competitiveness and its implications for higher education. In Education and the knowledge-based economy in Europe, ed. B. Jessop, N. Fairclough, and R. Wodak, 13-40. Rotterdam: Sense.

Laclau, E. 2005. On populist reason. London: Verso.

Laclau, E. 2014. The rhetorical foundations of society. London: Verso.

Leitch, S., and J. Roper. 1998. Genre colonization as a strategy: A framework for research and practice. Public Relations Review 24(2): 203-218.

Lewis, T. 2015. On Study: Giorgio Agamben and Educational Potentiality. London: Routledge.

Masschelein, J. 1996. Individualization, singularization and e-ducation (Between indifference and responsibility). Studies in Philosophy and Education 15: 97-105.

Masschelein, J. \& Simons, M. 2013. In Defence of the school: A public issue (J. McMartin, Trans.). Leuven, Belgium: E-ducation, Culture \& Society.

Marx, K. 1999 [1887]. Capital: A critique of political economy. Volume I, Book One: The Process of Production of Capital. Online Version: Marx/Engels Internet Archive (marxists.org) 1995, 1999. Retrieved March 6, 2020 https://www.marxists.org/archive/marx/works/1867-c1/.

Neef, D. 2009. Introduction: Re-thinking economics in the knowledge-based economy. In The economic impact of knowledge, ed. D. Neef, G.A. Siesfield, and J. Cefola, 3-16. Woburn: Butterworth-Heinemann.

Phillips, D. 2005. Economics as ideological fantasy. Dispensability of man by way of changing the nature of ideas. International Journal of Applied Semiotics 4(2): 9-34. 
Proctor, R.N., and L. Schiebinger (eds.). 2008. Agnotology: The making and unmaking of ignorance. Stanford: Stanford University Press.

Rancière, J. 1991. The ignorant schoolmaster. Five lessons in intellectual emancipation (K. Ross, Trans.). Stanford: Stanford University Press. (Original work published 1987)

Rancière, J. 1999. Dis-agreement: Politics and philosophy (J. Rose, Trans.). Minneapolis: University of Minnesota Press. (Original work published 1995)

Rancière, J. 2010. Dissensus: On politics and aesthetics (S. Corcoran, Ed. \& Trans). London: Continuum.

Roberts, J., and J. Armitage. 2008. The ignorance economy. Prometheus 26 (4): 335-354.

Standing, G. 2011. The precariat: The new dangerous class. London: Bloomsbury Academic.

Stankiewicz, Ł. 2018. Wizje uniwersytetu w polskiej debacie publicznej 2007-2009 [Visions of the University in the Polish Public Debate in the Years 2007-2009]. Kraków: Impuls.

Szkudlarek, T. 2010. Inner university, knowledge workers, and liminality. In The Routledge doctoral student's companion: Getting to grips with research in education and social sciences, ed. P. Thompson and M. Walker, 356-367. London: Routledge.

Szkudlarek, T. 2016. On the Politics of Educational Theory: Rhetoric, theoretical ambiguity, and the constructions of society. New York: Routledge.

Vlieghe, J. 2013. Experiencing (im)potentiality: Bollnow and Agamben on the educational meaning of school practices. Studies in Philosophy and Education 32(2): 189-203.

Vlieghe, J., and P. Zamojski. 2019. Towards an ontology of teaching. Thing-centred pedagogy, affirmation and love for the world. Cham: Springer.

Zeller, C. 2008. From the gene to the globe: Extracting rents based on the intellectual property monopolies. Review of International Political Economy 15(1): 86-115.

Publisher's Note Springer Nature remains neutral with regard to jurisdictional claims in published maps and institutional affiliations. 